\title{
INDIKASI KARTEL KOMUNDITAS STRATEGIS DALAM PERSPEKTIF HUKUM PERSAINGAN USAHA TIDAK SEHAT \\ (Studi Kajian Perlindungan Hukum)
}

Oleh:

\section{Parida Angriani}

\begin{abstract}
In general, the competition was fair, if done honestly but the competition was not always done honestly. The fraudulent acts one of which was the cartel. Cartels were agreements made by businesses to other businesses in similar production to influence prices and production process. The cartel action usually choose products that have strategic value, as well as production of meat and soy. In the production of strategic community such as meat and soy currently were alleged (indication) the occurence of a cartel. To avoid the se allegations, to marketing, production businesses must leave the Antimonopoly Law No.5/1999. Where in the legislation there was a ban on cartel action by businesses that contained in Article 11 of the law. However, the setting of the cartel was still considered less clear and complete, because it does not provide clear and unequivocal definition of the cartel as well as the type of the cartel. To avoid the vagueness of the norm government in formulating laws and should be careful and able to provide legal protection of a clear and unequivocal to the consumer to prevent arbitrary actions of businesses.
\end{abstract}

Keywords: Cartels, strategic community, and Unfair Competition.

\section{PENDAHULUAN}

Kesejahteraan rakyat tidak akan pernah benar-benar hadir apabila kebijakan negara tidak berpihak kepada masyarakat termasuk memberikan perlindungan dari para pelaku usaha yang bertidak dan berlaku curang atau tidak jujur dalam berusaha, misalnya tentang persekongkolan tender, oligopoli, trust, dan sebagainya yang merupakan tidankan curang dalam kegiatan usaha.

Dari berbagai perkara yang muncul dalam dunia usaha, pelanggaran yang paling

\footnotetext{
${ }^{1}$ Devi Meyliana, 2013, Hukum Persaingan Usaha
} (Studi Konsep Pembuktian Terhadap Perjanjian berdampak luas terhadap masyarakat adalah kartel. Pengertian kartel meliputi penetapan harga, pembagian wilayah dan pembatasan kuota produksi. Kartel merupakan tindakan yang sangat merugikan masyarakat, bahkan banyak negara memasukkan ke dalam tindakan ekstraorinary crime, karena dampaknya sangat signifikan terhadap dunia usaha. ${ }^{1}$ Dalam Pasal 11 Undang-Undang Nomor 5 Tahun 1999 Tentang Larangan Praktek Monopoli dan Persaingan Tidak Sehat (UU No. 5 Tahun 1999) mengatur

Penetapan Harga Dalam Persaingan Usaha), Malang: Setara Press, hlm. vii 
mengenai perjanjian mempengaruhi produksi sebagai perbuatan yang dilarang.

Perjanjian penetapan harga (price fixing) ${ }^{2}$ merupakan bentuk kesepakatan penetapah harga yang sama oleh pelaku usaha dengan pelaku usaha lainnya atau disebut dengan pesaingnya. Pada umumnya, perjanjian tersebut bertujuan untuk meningkatkan harga dan memaksimalkan keuntungan. Salah satu indikasi kartel adalah adanya keseragaman harga yang diawali dengan kelangkaan pasokan barang, sehingga terbentuknya harga yang diawali dengan kelangkaan pasokan barang, sehingga terbentuknya harga yang supra kompetitif, yang memaksa konsumen harus membeli barang lebih mahal dari semestinya. $^{3}$

Terbentuknya harga yang supra kompetitif, biasanya dilakukan pada impor pangan yang merupakan komonditas strategis. Impor tersebut membuka peluang untuk mempermainkan harga. Inilah yang membuat harga daging di negara kita tidak wajar, bahkan paling tinggi di dunia. Bayangkan, daging sapi yang diimpor dari Australia harganya Rp 40.000, tapi di sini dijual hingga Rp 90.000. Dibandingkan dengan negara tetangga seperti Malaysia, harga daging sapi di Indonesia juga dua kali lebih mahal. Laba yang dikeruk para pengusaha bisa mencapai puluhan triliun rupiah setiap tahun. Selama JanuariNovember tiga tahun lalu, misalnya, Indonesia mengimpor bahan-bahan pangan utama itu lebih dari 15 juta ton dengan nilai Rp 81,5 triliun. Ini yang menjelaskan pula kenapa importir daging sapi bersedia

\footnotetext{
${ }^{2}$ Ibid, hlm. ix

${ }^{3}$ Ibid.

${ }^{4}$ http://kartel-indonesia.blogspot.co.id/2013/02/kartelkomoditas-pangan.html
}

menyuap hingga miliaran rupiah buat mendapatkan kuota impor. ${ }^{4}$ Kartel ini tidak hanya untuk mengatur harga dan pemasaran produksi daging saja, melainkan komoditas lain, seperti jagung, kedelai, beras, gula, dan terigu. Kebutuhan akan impor pangan di Indonesia masih sangat besar seperti yang disampaikan oleh Moch. Maksum Machfoedz, dimana sembilan komoditas pangan nasional hampir semuanya impor. Disebutkan bahwa komoditas gandum dan terigu masih impor $100 \%$, bawang putih $90 \%$, susu $70 \%$, daging sapi $36 \%$, bibit ayam ras $100 \%$, gula $40 \%$, jagung $10 \%$, dan garam $70 \% .^{5}$

Kebutuhan yang besar akan pangan impor tersebut, menyebabkan lonjakan harga yang cukup signifikan dan sering terjadi dari beberapa tahun terakhir. Salah satu contoh yang menjadi pusat perhatian pada tahun 2013 terjadi lonjakan harga kedelai, yang menjadi hot toppik untuk diperbincangkan. Ketergantungan Indonesia akan kedelai impor sangat besar, hingga $70 \%$. Celakanya, tata niaga impor kedelai saat itu dikuasai kartel. Sedangkan di sisi lain, Kementerian Perdagangan justru memberikan izin impor kedelai kepada perusahaan-perusahaan yang terindikasi kartel dengan kuota sangat besar. Berdasarkan data penelitian Indef, ada tiga importir yang mendapat kuota terbesar, yakni PT FKS Multi Agro sebesar 210.600 ton (46,71 persen dari total alokasi impor), PT Gerbang Cahaya Utama 46.500 ton $(10,31$ persen), dan PT Budi Semesta Satria 42.000 ton $(9,31$ persen). Mereka menguasai

${ }^{5}$ https://roeshman.wordpress.com/2015/12/31/mengkr itisi-kebijakan-impor-pangan-pemerintahan-jokowijk-sebuah-catatan-akhir tahun 
299.100 ton atau 66,33 persen dari total kuota 450.900 ton. $^{6}$

Ketergantungan akan impor pangan di Indonesia inilah memberikan peluang besar kepada pelaku-pelaku usaha untuk menekan produksi. Sayangnya, tidak jarang tindakan kartel seperti ini difasilitasi kebijakan pemerintah dalam bentuk peraturan perundang-undangan sehingga kegiatan tersebut seolah-olah memiliki pembenaran yuridis.

Menginggat dampak kartel yang signifikan terhadap dunia bisnis, diperlukannya usaha preventif maupun refprensif atau tindakan pemerintah dalam hal ini sebagai pemberi jaminan atas kesejahteraan rakyatnya terutama konsumen haruslah memperhatikan lebih cermat tindakan-tindakan dalam persaingan usaha, sehingga hak-hak dari konsumen tidak terabaikan, tujuannya adalah untuk mencegah kesewenang-wenangan dari para pelaku-pelaku usaha yang bertindak sebagai penentu harga dalam prekonomian tidak melakukan tindak-tindakan yang bertentangan dengan hukum yang telah ada.

\section{PEMBAHASAN}

\section{Kerangka Teori}

Teori Perse rule, teori hukum murni dan teori utilytas yang digunakan sebagai pisau analisis untuk menjawab permasalahan yang terjadi. Pendekatan perse rule merupakan larangan yang bersifat jelas dan tegas, dan mutlak disebabkan prilaku yang sangat

${ }^{6} \mathrm{http}: / / \mathrm{www}$. suaramerdeka.com/v1/index.php/read/ce tak/2013/09/11/236478/Kartel- Kuasai-ImporKedelai

${ }^{7}$ Mustafa Kamal Rokan, Hukum Persaingan Usaha (Teori dan Praktiknya di Indonesia), Jakarta: Raja Grafindo Persada, 2012, hlm. 72. mungkin merusak persaingan sehingga tidak perlu lagi melakukan pembuktian akibat perbutan tersebut. Atau dengan kata lain pendekatan perse rule merupakan pendekatan dimana perbuatan dinyatakan sebagai pelanggaran dan dapat dihukum tanpa perlu melakukan pertimbangan apakah perbuatan tersebut mengakibatkan kerugian atau menghambat persaingan, ${ }^{7}$ lalu menggunaan teori preventif yang dikemukakan Philipus M.Hadjon yang memberikan kesempatan kepada masyarakat untuk menyampaikan keberatan terhadap kebijakan pemerintah sehingga pemerintah lebih berhati-hati dalam mengambil keputusan, ${ }^{8}$ serta Mengutip pendapat Kelsen, konsep penerapan hukum harus dengan pendekatan metode normative-yuridis yang bersih dari anasir non-yuridis seperti sosiologis, politis, historis, dan etika. Peraturan hukum selalu merupakan hukum positif (tertulis). ${ }^{9}$ Kemudian pada akhirnya meminjam teori (utility) Jeremy Bentham tujuan hukum ialah menjamin adanya kemamfaatan atau kebahagiaan sebanyakbanyaknya pada orang sebanyakbanyaknya. ${ }^{10}$

\section{Metode Penelitian}

Penelitian ini merupakan jenis penelitian yuridis normatif. Penelitian ini menggunakan dua metode pendekatan yaitu metode pendekatan Conseptual Approach dan Statute Approach. Conceptual approach adalah suatu pendekatan yuridis normatif

8 Phillipus M. Hadjon, Dalam Pakde Karwo Pintu Gerbang MEA 2015 Harus Dibuka, Jakarta: Prenadamedia Group, 2015, hlm. 303.

9 Teguh Prasetyo dan Abdul Halim Barkatullah, Filsafat, Teori, dan Ilmu Hukum, Raja Grafindo Persada, Jakarta, 2012, hlm. 205.

${ }^{10}$ Ibid, hlm.203. 
yang beranjak dari suatu perundangundangan dan doktrin-doktrin yang berkembang dalam ilmu hukum sedangkan metode pendekatan Statute Approach adalah penelitian yang dilakukan dengan menelaah peraturan Perundang-Undangan Nomor 5/1999 tentang Larangan Praktek Monopoli dan Persaingan Usaha Tidak Sehat, dan peraturan yang terkait seperti UndangUndang No 8/1999 tentang Perlindungan Konsumen.

\section{Hubungan Hukum Antara Produsen (Pelaku Usaha) dengan Konsumen.}

\section{a. Hubungan Langsung}

Hubungan langsung yang dimaksud pada bagian ini adalah hubungan antara produsen dan konsumen dengan konsumen yang terikat secara langsung dengan perjanjian. Tanpa mengabaikan jenis perjanjian-perjanjian lainnya, pengalihan barang dari produsen kepada konsumen, pada umumya dilakukan dengan perjanjian jual beli, baik yang dilakukan secara lisan maupun tertulis. Salah satu perjanjian tertulis yang dikenal adalah perjanjian baku, yaitu bentuk perjanjian yang banyak dipergunakan jika salah satu pihak sering berhadapan dengan pihak lain dalam jumlah yang banyak dan memiliki kepentingan yang sama. ${ }^{11}$

Perjanjian baku yang ditemukan dalam praktik pada dasarnya dilakukan bedasarkan asas kebebasan bekontrak ${ }^{12}$ sebagimana yang diatur dalam Pasal 1338 (1) KUHPerdata, yaitu bahwa semua

11 Ahmadi Miru, Prinsip-Prinsip Perlindungan Hukum Bagi Konsumen Di Indonesia, Jakarta: Raja Grafindo Persada, 2011, hlm. 34

12 Galuh Puspita Ningrum, Hukum Persaingan Usaha (Perjanjian dan Kegiatan yang Dilarang dalam perjanjian yang dibuat secara sah, berlaku sebagai undang-undang bagi mereka yang membuatnya. Sedangka pengertian sahnya perjanjian berdasarkan syarat sahnya perjanjian yang tercantum dalam Pasal 1320 KUHPerdata, mengenai kesepakan, kecakapan, objek, dan causa yang diperbolehkan undang-undang.

Namun demikian, dipenuhinya keempat syarat diatas belum menjamin kesempurnaan perjanjian yang dimaksud, karena masih ada ketentuan lain yang harus diperhatikan apakah perjanjian tersebut sah tanpa ada alasan pembatal, sehingga perjanjian tersebut mengikat sebagaimana mengikatnya undangundang. Ketentuan yang dimaksuda adalah kesempurnaan kata sepakat, karena apabila kata sepakat diberikan karena adanya paksaan, kekhilafan, atau penipuan, maka perjanjian tersebut tidak sempurna sehingga masih ada kemungkinan dibatalkan. ${ }^{13}$

\section{b. Hubungan Tidak Langusung}

Pada awal sejarah manusia, transaksi bisnis terjadi secara langsung antara produsen dan konsumen. Seiring dengan revolusi industri, transaksi usaha berkembang ke arah hubungan yang tidak langsung melalui suatu mata rantai distribusi, dari pelaku usaha, disalurkan atau didistribusikan kepada agen, lalu ke pengecer baru sampai konsumen. Dalam hubungan ini tidak terdapat hubungan kontraktual (perjanjian) antara produsen

Hukum Persaingan Usaha Di Indonesia), Yogjakarta: Aswaja Pressindo, 2013, hlm. 24

${ }^{13}$ Ibid, Dalam, Ahmadi Miru, hlm. 35 
dan konsumen. ${ }^{14}$ Hubungan tidak langsung yang dimaksud adalah hubungan antara produsen denga konsumen yang tidak terikat secara langsung dengan perjanjian, karena adanya pihak diantara pihak konsumen dengan produsen. ${ }^{15}$

Dalam tindakan kartel konsumen sebagai pihak yang lemah, dimana hubungan kontraktual mereka tidak ada secara langsung antara produsen yang memainkan harga dengan konsumen sebagai pihak pembeli, namun karena tindakan tersebut tidak baik berdampak pada kerugian yang besar tehadap konsumen. Ketiadaan hubungan langsung dalam bentuk perjanjian antara pihak produsen (pelaku usaha) dengan konsumen ini tidak berarti bahwa konsumen yang dirugikan tidak dapat menuntut ganti kerugian kepada produsen (pelaku usaha) dengan siapa dia tidak memiliki hubungan perjanjian, karena dalam hukum perikatan tidak hanya perjanjian yang melahirkan perikatan melainkan perikatan dapat timbul karena perjanjian dan undangundang. ${ }^{16}$

Perikatan yang lahir karena undangundang dapat diklasifikasian lagi menjadi yang lahir karena undang-undang dan karena perbuatan manusia yang melanggar hukum yang merupakan hal yang penting dalam kaitannya dengan perlindungan konsumen. Perbuatan meanggar hukum dalam KUPHPerdata diatur dalam Pasal 1365, yaitu sebagai berikut: "Tiap perbuatan melanggar

${ }^{14}$ https://www.google.seacrhFillinAnggraini.com/diak ses/26/03/2016/-hubungan hukum pelaku usaha dan konsumen. hukum yang menyebabkan kerugian kepada orang lain, mewajibkan orang yang karena salahnya menerbitkan kerugian itu menganti kerugian tersebut".

Berdasarkan ketentuan diatas,maka konsumen yang dirugikan karena tindakan pelaku usaha yang curang dalam memainkan harga dengan mengatur produksi komunditas strategis (kartel) seperti daging, kedelai, bawang, dan segala jenis kebutuhan pagan (komunditas stategis) lainnya, tidak perlu harus terikat perjanjian secara langsung untung dapat menuntut ganti kerugian.

\section{c. Hak dan Kewajiban Konsumen}

Menginggat banyaknya tindakan kartel dalam persaingan usaha serta mengingat melambungnya harga kedelai, daging, bawang maupun komuditas strategis lainnya yang kerap terjadi saat ini yang di duga peningkatan harga tersebut terjadi karena adanya penekanan jumlah produksi pada komuditas strategis yang menyebabkan harga kebutuhan pokok melonjak dipasaran, sehingga sangat perlu bagi konsumen untuk memahami hukum yang mengatur tentang persaingan usaha untuk melindungi hak-hak mereka serta mampu untuk melakukan perlawanan hukum yang berlaku untuk menjerat pelaku usaha curang.

Berdasarkan pertimbangan tersebut, maka perlu diketahui apa saja yang menjadi hak maupun kewajiban konsumen.

\footnotetext{
${ }^{15}$ Loc-Cit, Dalam Ahmadi Miru

${ }^{16}$ Ibid.
} 


\section{Hak-Hak Konsumen}

Dalam Pasal 4 UUPK (UndangUndang Perlindungan Konsumen) dirumuskan hak-hak konsumen sebagai berikut: ${ }^{17}$

a. Hak atas kenyamanan, keamanan, dan keselamatan dalam mengkonsumsi barang dan/atau jasa.

b. Hak untuk memilih barang dan/jasa serta mendapatkan barang dan/atau jasa tersebut sesuai dengan nilai tukar dan kondisi dan jaminan yang dijanjikan.

c. Hak atas informasi yang benar, jelas, dan jujur mengenai kondisi dan jaminan barang dan/ atau jasa.

d. Hak untuk didengar pendapat dan keluhannya atas barang dan/atau jasa yang digunakan.

e. Hak untuk mendapat advokasi, perlindungan konsumen, dan upaya penyelesaian sengketa perlindungan konsumen secara patut.

f. Hak untuk mendapat pembinaan dan pendidikan konsumen.

g. Hak untuk diperlakukan atau dilayani seacara benar dan jujur serta tidak diskriminatif.

h. Hak untuk mendapatkan kompensasi, ganti rugi dan/atau penggantian jika barang dan/atau jasa yang diterima tidak sesuai dengan perjanjian dan tidak sebagaimana mestinya.

i. Hak-hak yang diatur dalam ketentuan perundangundangan lain.

\section{Kewajiban konsumen}

Dalam Pasal 5 UUPK dirumuskan kewajiban konsumen sebagai berikut:

a. Membaca atau mengikuti petunjuk informasi dan prosedur pemakaian atau pemanfaatan barang dan/atau jasa, demi keamanan dan keselamatan.

b. Beritikad baik dalam melakukan transaksi pembelian barang dan/atau jasa.

c. Membayar sesuai dengan nilai tukar yang disepakati.

d. Mengikuti upaya penyelesaian hukum sengketa penyelesaian konsumen secara patut.

Bedasarkan pemaparan di atas penulis dapat menyimpulkan bahwa dalam persaingan usaha, konsumen atau masyarakat dapat dilindungi hak-haknya dari tindakan pelaku usaha yang tidak patut tidak terkecuali hak-hak konsumen yang sering diabaikan oleh pelaku usaha dalam menjalankan usahanya dengan membuat perjanjian kartel, khususnya indikasi kartel terhadap komunditas strategis yang sedang hangat dipebincangkan.

17 Shidarta, Hukum Perlindungan Konsumen Indonesia, Jakarta: Gramedia Widiasarana Indonesia, 2006 
Merujuk dari Undang-Undang No 8 Tahun 1999 tentang Perlindungan Konsumen, maka menurut hemat penulis apabila terjadi kartel terhadap komunditas strategis hak-hak konsumen yang perlu dilindungi adalah sebagai berikut:

a. Hak untuk dilindungi dari akibat negatif persaingan curang,

b. Hak untuk memperoleh ganti rugi jika terjadi kartel,

c. Hak untuk memperoleh kebutuhan hidup yang diperlukan,

d. Hak untuk memperoleh penyelesaian hukum akibat perbuatan pelaku usaha.

Dalam pemasaran antara produsen atau pelaku usaha utama tidak memiliki hubungan kontraktual secara langsung dengan konsumen, sehingga posisi tawar konsumen sangat lemah dan perlu di lindungi. maka perlu adanya payung hukum yang lebih tegas dalam memberikan perlindungan hukum terhadap konsumen, agar hak-hak konsumen tidak terabaikan perlu adanya penerapan secara perse rule.

Sehingga menurut hemat penulis, Pendekatan perse rule baik diterapkan untuk memberikan perlindungan hukum maupun jaminan kepastian hukum bagi konsumen sehingga dengan adanya penerapan perse rule tersebut memberikan jaminan terhadap hak-hak konsumen, karena tanpa harus melihat dampak atau akibat kartel itu lebih lanjut, tetapi dirasa akan sangat merugikan bahkan mengabaikan hak-hak konsumen maka tindakan tersebut harus ditindak lanjuti.

Hal tersebut seirama dengan teori Hals Kelsen bahwa hukum yang tertinggi adalah aturan yang tertulis yang dapat memberikan jaminan bagi masyarakat. Pendapat lain yang tidak kalah penting adalah pendapat dari
Jeremi Betcham yang menyatakan bahwa tujuan pembentukan hukum adalah unrtuk menjamin kebahagian dan kenyamanan untuk orang lain atau orang banyak.

Dengan demikian dalam pembentukan peraturan perundang-undangan haruslah memberikan kepastian hukum bagi banyak pihak dan perlu adanya kordinasi yang jelas antara pemerintah dan aparat penegak hukum dalam menegakan hukum sehingga hal tersebut sejalan dengan teori preventif yang dicetuskan oleh Philippus M. Hadjon dan dengan terjalinya kerjasma yang baik serta adanya kepastian hukum dalam peraturan perundang-undangan akan dapat mengurangi praktek kartel serta mencegah munculnya praktek-praktek kartel pada komununditas strategis dalam persaingan usaha yang terjadi di Indonesia

\section{KESIMPULAN}

Dalam tindakan kartel konsumen sebagai pihak yang lemah, dimana hubungan kontraktual mereka tidak ada secara langsung antara produsen yang memainkan harga dengan konsumen sebagai pihak pembeli. Perlindungan hukum konsumen terhadap adanya kartel kedelai berupa hak-hak yang harus dilindungi oleh hukum.

a. berhak untuk dilindungi dari akibat negatif persaingan;

b. hak untuk memperoleh ganti rugi jika terjadi kartel;

c. hak untuk memperoleh kebutuhan hidup yang diperlukan, dan;

d. hak untuk memperoleh penyelesaian hukum akibat perbuatan pelaku usaha.

Diharapkan bagi pemerintah untuk lebih meningkatkan mutu dan kualitas aturan 
hukum yang memberikan perlindungan hukum terhadap konsumen dengan menyusun kembali Undang-Undang No. 5/1999 tersebut karena sudah tidak sesuai dengan perkembangan jaman, serta diharapkan kepada konsumen atau masyarakat untuk lebih peka terhadap hakhak mauapun kewajibannya dalam persaingan usahan.

\section{DAFTAR PUSTAKA}

\section{Buku dan Karya Ilmiah}

Meyliana, Devi, Hukum Persaingan Usaha (Studi Konsep Pembuktian Terhadap Perjanjian Penetapan Harga Dalam Persaingan Usaha), Malang: Setara Press, 2013.

Miru, Ahmadi, Prinsip-Prinsip Perlindungan Hukum Bagi Konsumen Di Indonesia, Jakarta: Raja Grafindo Persada, 2011.

Ningrum, Galuh Puspita, Hukum Persaingan Usaha (Perjanjian dan Kegiatan yang Dilarang dalam Hukum Persaingan Usaha Di Indonesia), Yogyakarta: Aswaja Pressindo, 2013.

Pakde Karwo Pintu Gerbang MEA 2015 Harus Dibuka, Jakarta: Prenadamedia Group.

Prasetyo, Teguh, Abdul Halim Barkatullah, Filsafat, Teori dan Ilmu Hukum Pemikiran Menuju Masyarakat yang Berkeadilan dan Bermatabat, Jakarta: Raja Grafindo Persada, 2012.
Rokan, Mustafa Kamal, Hukum Persaingan Usaha (Teori dan Praktiknya di Indonesia), Jakarta: Raja Grafindo Persada, 2012.

Shidarta, Hukum Perlindungan Konsumen Indonesia, Jakarta: Gramedia Widiasarana Indonesia, 2006.

\section{Peraturan Perundang-undangan}

Kitab Undang-Undang Hukum Perdata Nomor. 566. Tahun 1924.

Undang-undang Nomor 5 Tahun 1999 tentang Larangan Monopoli dan Persaingan Usaha Tidak Sehat.

Undang-Undang Nomor 42 Tahun 1999 tentang Perlindungan Konsumen.

\section{Internet}

http://kartelindonesia.blogspot.co.id/2013/02/kar tel-komoditas-pangan.html

https://roeshman.wordpress.com/2015/12/31 /mengkritisi-kebijakan-imporpangan-pemerintahan-jokowi-jksebuah-catatan-akhir tahun

http://www.suaramerdeka.com/v1/index.php /read/cetak/2013/09/11/236478/Karte 1- Kuasai-Impor-Kedelai

https://www. Google.search-Fillin Anggraini.com/diakses/26/03/2016/hubungan hukum pelaku usaha dan konsumen 